\title{
RISS Stage
}

National Cancer Institute

\section{Source}

National Cancer Institute. RISS Stage. NCI Thesaurus. Code C141392.

A plasma cell myeloma stage defined according to the Revised International Staging System (RISS) criteria. 